\title{
The Influence of Tetranychus urticae Koch (Acari: Tetranychidae) Life Table and Reproductive Parameters by Applying Si on Bean at Library Condition
}

\author{
Elahe Sadeghi' ${ }^{1}$, Reza Vafaei Shoushtari ${ }^{2}$, Hamid Madani ${ }^{3}$ \\ ${ }^{1}$ Entomology Student Department, Arak Branch, Islamic Azad University, Arak, Iran \\ ${ }^{2}$ Faculty of Entomology, Arak Branch, Islamic Azad University, Arak, Iran \\ ${ }^{3}$ Faculty of Agriculture, Arak Branch, Islamic Azad University, Arak, Iran \\ Email: elahe.sadeghi25302yahoo.com
}

How to cite this paper: Sadeghi, E., Shoushtari, R.V. and Madani, H. (2016) The Influence of Tetranychus urticae Koch (Acari: Tetranychidae) Life Table and Reproductive Parameters by Applying Si on Bean at Library Condition. Advances in Entomology, 4, 260-267.

http://dx.doi.org/10.4236/ae.2016.45027

Received: August 17, 2016

Accepted: September 16, 2016

Published: September 19, 2016

Copyright $\odot 2016$ by authors and Scientific Research Publishing Inc. This work is licensed under the Creative Commons Attribution International License (CC BY 4.0).

http://creativecommons.org/licenses/by/4.0/

\begin{abstract}
Two-spotted spider mite, Tetranychus urticae Koch, is one of the important pests of bean, which can cause severe damages on it. Silicon is one of the micronutrient elements, as its spray on the leaves can decrease the population of the pest. In this research, the impact of four different doses of $\mathrm{Si}(0,1,1 / 5,2 \mathrm{ppm})$ was investigated on biological and population growth parameters of $T$. urticae. The experiments were carried out in Petri dishes in an incubator at $25^{\circ} \mathrm{C} \pm 2{ }^{\circ} \mathrm{C}, 65 \% \pm 5 \% \mathrm{RH}$ and $16 \mathrm{~L}: 8$ D. The duration of developmental stage was significantly affected by $\mathrm{Si}$ dose. The longest immature period, the shortest longevity of females and the shortest oviposition period were obtained at $2 \mathrm{ppm}$. In addition, Si dose significantly affected population growth parameters of the mite. The intrinsic rate of natural increase $(\mathrm{rm})$ of the mite ranged from 0.246 to 0.215 day which lowest and the highest values were at $2 \mathrm{ppm}$ and control plants, respectively. The lowest net reproductive rate (R0) and finite rate of increase $(\lambda)$ of the mite and the highest value of mean generation time (T) and doubling time (DT) were estimated at $2 \mathrm{ppm}$. The results of this peruse represented that $2 \mathrm{ppm}$ had better potential for decreasing the population of the two-spotted spider mite, and it can be used in the mite integrated pest management programs.
\end{abstract}

\section{Keywords}

Two-Spotted Spider Mite, Si, Biological Parameters, Intrinsic Rate of Natural Increase 


\section{Introduction}

Bean is one of the most critical crops in the world and makes up stable natural protein for human. Silicon is the second most abundant constituent in the earth's crust [1]. It constitutes $27.7 \%$ of the total weight in soil after the oxygen (47\%). It ranges from 200

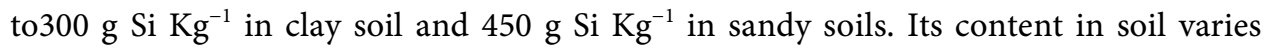
from $<1 \%$ to $45 \%$ by dry weight. The traditional practice of collecting the ashes from the back yard of houses supplies not only potash but also silicon. Silicon is an agronomically important fertilizer element that enhances plant tolerance to abiotic stresses. Silicon fertilizer has a double effect on the soil-plant system as under. 1) Improved plant-silicon nutrition reinforces plant-protective properties against diseases, insect attack, and unfavorable climatic conditions; 2) soil treatment with biogeochemical active silicon substances optimizes soil fertility through improved water, physical and chemical soil properties, and maintenance of nutrients in plant-available forms [2].

Silicon has generally not been considered essential for plant growth, although it is well recognized that many plants, particularly Poaceae, have substantial plant tissue concentrations of this element. For many years, silicon deficiency in crops went unrecognized, and this element was widely regarded as non-essential for plant growth, although often present in the highest concentration in inorganic constituents. However, there is now a greater consensus amongst scientists in the role of silicon as a "functional" plant nutrient. Silica content in the plant is reported to play an important role in strengthening the cell walls of plants [3]. In Florida, researchers found that after applying $20 \mathrm{t} / \mathrm{ha}$ of TVA slag to a muck soil, there was a significant decrease in leaf freckling in sugarcane. Furthermore, with improved silicon nutrition, there was an increase in sugarcane resistance to the stem borer Diatraea saccharalis F. [4]. In the greenhouse, sugarcane varieties were artificially inoculated with $E$. saccharina and treated with three doses $(0,5$ and $10 \mathrm{t} / \mathrm{ha})$ of calcium silicate. At $10 \mathrm{t} / \mathrm{ha}$ calcium silicate, there was a reduction of $30 \%$ in borer damage and $20 \%$ in borer mass. The most susceptible varieties showed the highest silicon uptake and the greatest response. Of the four carriers tested, stalkborer incidence declined as follows: South African calcium silicate > imported USA calcium silicate $>$ local Slagment $>$ flyash. In the field experiment, similar results were recorded [5].

Other experiments in Asia showed that, on rice, silicic acid at concentrations as low as $0.01 \mathrm{mg} \mathrm{Si} / \mathrm{ml}$ was an active sucking inhibitor against the brown planthopper (Nilaparvata lugens (Stal) [6]. Furthermore, at high levels of silicon, fewer planthopper nymphs became adults and there was a decrease in adult longevity and female fecundity [4].

High silicon content contributed to maize (Zea mays L.) resistance to stalkborer (Chilo zonellus Swinhoe) damage. Similarly, in Benin, researchers evaluated the effects of silica application to maize on the borer, Sesamia calamistis Hampson (Lepidoptera: Noctuidae). They applied sodium metasilicate $\left(\mathrm{Na}_{2} \mathrm{SiO}_{3.5} \mathrm{H}_{2} \mathrm{O}\right)$ at a rate of $0,0.56$ and $0.84 \mathrm{~g} \mathrm{Si} /$ plant. They recorded that an increasing silica supply reduced larval survival from $26.0 \%$ (control) to $4.0 \%$ at $0.56 \mathrm{~g} \mathrm{Si} /$ plant [7]. Additionally, maize resistance to the 
second generation of Ostrinia nubilalis Hübner (Lepidoptera: Pyralidae) was significantly correlated with the silica content in the sheath and collar tissue [4].

Host plant resistance can be a fundamental factor of a successful integrated pest management (IPM) system. Integration of resistant plants with other pest control methods results in conservation of beneficial natural enemies and decreased usage of pesticides [8].

Tetranychus urticae is an important pest of a variety of agricultural crops [9]. Adults and immatures feed primarily on leaves producing tiny gray or silvery spots known as stippling damage. Damage to the leaves inhibits photosynthesis, and severe infestations can result in premature leaf fall, shoot dieback, and decreased plant vigor [10]-[12]. Although chemical control is a common method, it cannot decrease number of mites. Therefore, the main target of the present study is to determine the effects of Si on the demographic parameters of $T$. urticae.

\section{Material and Methods}

This experiment was carried out at the laboratory of Arak Azad University. Red bean cultivar Akhtar was used as host plant. Cultivar was selected by advisement of plant protection experts in khomein research center. Seeds were drenched $24 \mathrm{~h}$. before planting and they were planted in pots (10 liters in size) that were filled with cocopeat and perlite (1:1) in a hydroponic system. The pots were kept in a greenhouse at $28^{\circ} \mathrm{C} \pm$ $2^{\circ} \mathrm{C}$, with a light intensity of 13,000 Lux and were fed by the nutrient solution (Rash) three times daily [13]. The mites collected from greenhouse of Markazi province, Iran. The mites were maintained in potted young akhtar plants in a laboratory at $26^{\circ} \mathrm{C} \pm 11^{\circ} \mathrm{C}$, $75 \%-80 \%$ relative humidity (RH), and $14 \mathrm{~h}$ light/10h dark cycle with no acaricide exposure for a long time [14].

They were separately reared on bean leaves which were sprayed with different value of $\mathrm{Si}$. According to the amount $\mathrm{Si}$ that bean plants need for growing and previous studies, the effect of various doses of $\mathrm{Si}(0,1,1.5,2 \mathrm{ppm})$ on life parameters and reproductive parameters of the spider mite were evaluated on $3 \mathrm{~cm}$ diameter leaf discs placed on soppy cotton in a $3 \mathrm{~cm}$ diameter Petri-dish with $1.5 \mathrm{~cm}$ diameter hole was drilled and covered with ruching for ventilation. Water was daily added to cotton for keeping the leaves fresh [15].

The experiment was conducted as split-plot in a complete randomized design with 100 replications. Five adult female mites were abandoned on the leaf disc per module. After $72 \mathrm{~h}$., the damage score of the leaf discs, the number of eggs and the percentage of dead mites were registered. The damage was determined pursuant to a damage score method [16]-[19].

Female and male spider-mite cohorts were situated a pair on a leaf disc. The mites were abolished after $3 \mathrm{~h}$. and only one egg was retained on each leaf disc. Units were surveyed every $12 \mathrm{~h}$ (at 7 am and $7 \mathrm{pm}$ ). After adult emanate, females were copulated with males taken from the colony of the mite on the same cultivar. Then the duration of egg, larva, protonymph and deutonymph, adult longevity, fecundity and mortality of 
the mite were registered for each sample the death of the last mite [18].

All population growth parameters were estimated, according to Carry's formula [20]. The All statistical analyses were carried out using software of Microsoft Excel 2003 [21] and SPSS 17.0 [22].

\section{Results}

\subsection{Developmental Times of Immature Stages}

The developmental times of immature stages (days) of Tetranychus urticae on bean plants amended with different Si ppm are reported in Table 1. Analysis of variance indicated significant differences in duration of immature stages of Tetranychus urticae in different levels of $\mathrm{Si}$. ( $\mathrm{F}=4.76, \mathrm{P}=0.004)$. The results showed that the maximum duration of incubation were happen in 2 and $1.5 \mathrm{ppm}$ samples of $\mathrm{Si}$ and the minimum were happen in $0 \mathrm{ppm}$. T. urticae eggs hatched to six legged larvae in the shortest duration of $1.32 \pm 0.09$ Days and the longest duration of $1.80 \pm 0.10$ days (Table 1 ). No significant variations were observed between samples for nymphal periods $(\mathrm{F}=2.74, \mathrm{P}=0.05)$. The shortest immature stages of host were registered for $0 \mathrm{ppm}$ trial.

\subsection{The Biological and Reproduction Parameter}

The biological and reproduction parameter of mature stages (days) of Tetranychus urticae on bean plants amended with different $\mathrm{Si}$ ppm are calculated and presented in Table 2. In this study female and male longevity were affected by different doses of $\mathrm{Si}$ $(\mathrm{F}=4.92, \mathrm{P}=0.004 \quad \hat{o})$ and $(\mathrm{F}=4.92, \mathrm{P}=0.004$ 우 $)$. The highest female longevity was recorded for 0 and $1 \mathrm{ppm}$ samples, while the shortest was recorded for $2 \mathrm{ppm}$ samples (Table 2). In $0 \mathrm{ppm}$ test male longevity was the maximum and the minimum was in 1.5 and $2 \mathrm{ppm}$. Analysis of variance indicated significant differences in duration of oviposition stages of Tetranychus urticae in different levels of $\mathrm{Si}$. $(\mathrm{F}=4.67, \mathrm{P}=0.005)$. According to the Table 2, the longest oviposition term was expressed about 0 and $1 \mathrm{ppm}$ samples, as the shortest oviposition term was reported for $2 \mathrm{ppm}$ test. There was no considerable variation about total fecundity.

\subsection{Population Growth Parameters}

The population growth parameters of Tetranychus urticae on bean plants amended with different Si ppm is presented in Table 3. Analysis of variance indicated significant

Table 1. Mean $( \pm \mathrm{SE})$ developmental times of immature tages days of Tetranychus urticae on Bean plants amended with different Si.

\begin{tabular}{ccccc}
\hline Si $(\mathrm{ppm})$ & Incubation & Larval period & Nymph period & Total immature stage \\
\hline 0 & $3.17 \pm 0.08$ & $1.32 \pm 0.09$ & $3.62 \pm 0.08$ & $8.22 \pm 0.10$ \\
1 & $3.40 \pm 0.09$ & $1.46 \pm 0.08$ & $3.67 \pm 0.07$ & $8.52 \pm 0.13$ \\
1.5 & $3.55 \pm 0.09$ & $1.73 \pm 0.09$ & $3.62 \pm 0.13$ & $8.90 \pm 0.17$ \\
2 & $3.57 \pm 0.08^{*}$ & $1.80 \pm 0.10^{*}$ & $3.97 \pm 0.10^{*}$ & $9.37 \pm 0.14^{*}$ \\
\hline
\end{tabular}

${ }^{\star}$ In columns, means followed by different letters are significantly different $(\mathrm{p}<0.05$; Tukey test). 
Table 2. Mean $( \pm \mathrm{SE})$ biological and reproduction parameter of mature stages (days) of Tetranychus urticae on bean plants with amended with different Si ppm.

\begin{tabular}{cccccc}
\hline $\begin{array}{c}\mathrm{Si} \\
(\mathrm{ppm})\end{array}$ & $\begin{array}{c}\text { Female } \\
\text { longevity }\end{array}$ & $\begin{array}{c}\text { Pre-oviposition } \\
(\text { day })\end{array}$ & $\begin{array}{c}\text { Oviposition } \\
(\text { day })\end{array}$ & $\begin{array}{c}\text { Post-oviposition } \\
(\text { day })\end{array}$ & Total fecundity \\
\hline 0 & $16.00 \pm 1^{*}$ & $8.50 \pm 0.01$ & $13.83 \pm 0.1$ & $1.10 \pm 0.17$ & $75.10 \pm 5.17$ \\
1 & $15.57 \pm 1.10$ & $7.28 \pm 1$ & $13.10 \pm 1.07$ & $1.20 \pm 0.14$ & $75.01 \pm 5.85$ \\
1.5 & $13.15 \pm 0.99$ & $6.38 \pm 0.5$ & $11.90 \pm 0.92$ & $1.15 \pm 0.17$ & $67.55 \pm 7.60$ \\
2 & $11.95 \pm 0.41$ & $5.62 \pm 0.34^{\star}$ & $9.50 \pm 0.58^{\star}$ & $1.13 \pm 0.11$ & $65.04 \pm 3.72^{\star}$ \\
\hline
\end{tabular}

${ }^{\star}$ In columns, means followed by different letters are significantly different $(\mathrm{p}<0.05$; Tukey test).

Table 3. Mean $( \pm \mathrm{SE})$ population growth parameters of Tetranychus urticae on bean plants amended with different Si.

\begin{tabular}{cccccc}
\hline $\begin{array}{c}\mathrm{Si} \\
(\mathrm{ppm})\end{array}$ & $\begin{array}{c}\text { Intrinsic rate of } \\
\text { natural increase }\end{array}$ & $\begin{array}{c}\text { Net reproductive } \\
\text { rate }\end{array}$ & $\begin{array}{c}\text { Finite rate of } \\
\text { increase }\end{array}$ & $\begin{array}{c}\text { Doubling } \\
\text { time }\end{array}$ & $\begin{array}{c}\text { Mean generation } \\
\text { time }\end{array}$ \\
\hline 0 & $0.252 \pm 0.004$ & $35.7 \pm 0.01$ & $1.30 \pm 0.005$ & $2.7 \pm 0.04$ & $14.6 \pm 0.23$ \\
1 & $0.230 \pm 0.004$ & $36.2 \pm 1$ & $1.29 \pm 0.007$ & $2.8 \pm 0.05$ & $15 \pm 0.16$ \\
1.5 & $0.232 \pm 0.006$ & $31.3 \pm 0.5$ & $1.28 \pm 0.009$ & $2.9 \pm 0.08$ & $15 \pm 0.19$ \\
2 & $0.220 \pm 0.003$ & $27.6 \pm 0.34$ & $1.25 \pm 0.004$ & $3.1 \pm 0.05$ & $15.9 \pm 0.26$
\end{tabular}

${ }^{*}$ In columns, means followed by different letters are significantly different $(\mathrm{p}<0.05$; Tukey test).

differences about intrinsic rate of natural increase ( $\mathrm{rm}$ ) of Tetranychus urticae in different levels of $\mathrm{Si}$. ( $\mathrm{F}=7 / 25, \mathrm{p}<0 / 001)$. The least intrinsic rate of natural increase was observed in $2 \mathrm{ppm}$ treatment, whenever the most was recorded in $0 \mathrm{ppm}$. The greatest net reproductive rate (R0) was registered for $0 \mathrm{ppm}$ test, as the lowest was registered for $2 \mathrm{ppm}$ trial. The observation about doubling time (DT) showed significant diversity (Table 3). The highest value of mean generation time (T) was observed about $2 \mathrm{ppm}$ assay, and the lowest was recorded for $0 \mathrm{ppm}$ assay.

\section{Discussion}

This study investigates that the different levels of Si have effect on life table and reproductive parameters of Tetranychus urticae on bean cultivar akhtar at library condition. The pests have different survival, development and reproductive rates on the host species and cultivars because plants vary greatly in suitability as hosts. Shorter development time and high reproduction of pests on host plans demonstrate greater suitability of those plants indicate greater suitability of those plants for colonization of pests [23]. The outcome of this etude confirmed the previous studies regarding effect of quality of host plant on the pest biology.

According to the previous studies, developmental time of immature stages include 2.37 (day) larval period, 6 (day) nymph period, and 15.375 (day) total immature stage [24]. Developmental time of immature stages in $2 \mathrm{ppm}$ assay showed the most and 0 ppm test showed the least. Due to significant increase of immature stages growth, the adult longevity and egg number decrease [25]. 
The population parameters $\left(r, \mathrm{R}_{0}, \lambda\right.$, and $\left.\mathrm{T}\right)$ are the obtained parameters, computed based on the presumption, which the environmental elements are constant and the structure population structure reaches a stable age-stage distribution as time approach infinity [26]. The intrinsic rate is a perfect parameter to reveal and compare the potential of insect populations under different treatments. It is practical application in pest management, however, is limited [8]. The maximum of this parameter makes clear that host plant is suitable for development of pest and the minimum of it means the host is not fit [27]. Pursuant to prior perusal, there is a positive correlate between leaf $\mathrm{N}$ and oviposition rate of Tetranychus urticae [28] and Tetranychus pacificus [29]. Variation of applying elements can be the main reason of increase or decrease of oviposition rate. In the present study, population growth parameters were significantly effect from $\mathrm{Si}$ treatments and the lowest amount of intrinsic rate of natural increase was recorded in 0 ppm test.

Therefore, the use of nutrition elements such as Si can help to success an integrated pest management program. Various rates of resistance to tetranychus urticae were observed in red bean akhtar cultivar by using different dose of Si. The best dose of Si for bridling $T$. urticae is 2 ppm value.

Validation of silicon application for pest control, identification of satisfaction silicon sources, and their optimal dosages for effective pest control in different crops, and integration of silicon applications with biological control for ecologically sustainable pest and disease management can be future researchers' topics.

\section{Acknowledgements}

This research has been supported by Department of Entomology, Arak Azad University of Iran, which is greatly appreciated.

\section{References}

[1] Ehrlich, H.L. (1981) Geomicrobiology. Marcel Dekker Inc., New York, 393.

[2] Meena, V.D., Dotaniya, M.L., Coumar, V., Rajendiran, S., Ajay, Kundu, S. and Subba Rao, A. (2014) A Case for Silicon Fertilization to Improve Crop Yieldsin Tropical Soils. Proceedings of the National Academy of Sciences, India, Section B: Biological Sciences, 84, 505-518. http://dx.doi.org/10.1007/s40011-013-0270-y

[3] Painter, R.H. (1951) Insect Resistance in Crop Plants. Macmillan, New York. http://dx.doi.org/10.1097/00010694-195112000-00015

[4] Laing, M.D., Gatarayiha, M.C. and Adandonon, A. (2016) Silicon Use for Pest Control in Agriculture: A Review. https://www.researchgate.net/publication/228760373

[5] Keeping, M.G. and Meyer, J.H. (2003) Effect of Four Sources of Silicon on Resistance of Sugarcane Varieties to Eldana saccharina Walker (Lepidoptera: Pyralidae). South African Sugar Technologists' Association, 77, 99-103.

[6] Yoshihara, T.K., Sogawa, M.D., Pathak, B.O. and Sakamura, S. (1979) Soluble Silicic Acid as a Sucking Inhibitory Substance in Rice against the Rice Brown Planthopper (Delphacidae: Homoptera). Entomologia Experimentalis et Applicata, 26, 314-322. http://dx.doi.org/10.1111/j.1570-7458.1979.tb02932.x 
[7] Sétamou, M.F., Schulthess, F., Bosque-Perez, N.A. and Thomas-Odjo, A. (1993) Effect of Plant $\mathrm{N}$ and Sion the Bionomics of Sesamia calamistis Hampson (Lepidoptera: Noctuidae).

Bulletin of Entomological Research, 83, 405-411.

http://dx.doi.org/10.1017/S000748530002931X

[8] Lorenzen, J., Balbyshev, N., Lafta, A., Casper, H., Tina, X. and Sagredo, B. (2001) Resistant Potato Selections Contain Leptine and Inhibit Development of the Colorado Potato Beetle (Coleoptera: Chrysomelidae). Journal of Economic Entomology, 94, 1260-1267. http://dx.doi.org/10.1603/0022-0493-94.5.1260

[9] Jeppson, L.R., Baker, E.W. and Keifer, H.H. (1975) Mites Injurious to Economic Plants. University of California Press, Berkely, 614 pp.

[10] Zhang, Z.Q. (2003) Mites of Greenhouses: Identification, Biology and Control. CABI Publishing, Cambridge, UK, 244 pp.

[11] Meck, E.D., Kennedy, G.G. and Walgenbach, J.F. (2013) Effect of Tetranychus urticae (Acari: Tetranychidae) on Yield, Quality, and Economics of Tomato Production. Crop Protection, 52, 84-90. http://dx.doi.org/10.1016/j.cropro.2013.05.011

[12] Kamelmanesh, M., Hesami, asah., Namayandeh, A., Ahmadi, B. and Dorri, H.R. (2010) Evaluation of Resistance Mechanism of Some Navy Bean Genotypes to Two-Apotted Spider Mite (Tetranychus urticae). Plant Protection Journal, 2, 111-125.

[13] Mohammadi, S., Seraj, A.A. and Rajabpour, A. (2015) Evaluation of Six Cucumber Greenhouse Cultivar for Resistance to Tetranychus turkestani (Acari: Tetranychidae). Crop Protection, 4, 545-556.

[14] Zhang, Q., Ding,L., Li, M., Cui, W., Ding, W., Luo, J. and Zhang, Y. (2013) Action Modes of Aloe vera L. Extracts against Tetranychus cinnabarinus Boisduval (Acarina: Tetranychidae). Advances in Bioscience and Biotechnology, 4, 117-122.

[15] Leyla, M., Jabraeil, R., Mehdi, H., Mojgan, M.T. and Pejman, T. (2015) Biological and Population Growth Parameters of Two-Spotted Spider Mite, Tetranychus urticae Koch (Acari: Tetranychidae) on Cucumber: Effect of Different Vermicompost: Soil Ratios. Plant Pest Research, 6, 13-44.

[16] Nihoul, P.T., Hance, B.M. and Van-Impe, G. (1992) Physiological Aspect of Damage Caused by Spider Mite on Tomato Leaflets. Journal of Applied Entomology, 113, 487-492. http://dx.doi.org/10.1111/j.1439-0418.1992.tb00693.x

[17] Gimenes-Ferrer, R.M., Scheerens, J.C. and Erb, W.A. (1993) In Vitro Screening of 76 Strawberry Cultivars for Two-Spotted Spider Mite Resistance. Horticultural Science, 28, 841-844.

[18] Smith, M.C. (2005) Plant Resistance to Arthropods: Molecular and Conventional Approaches. Springer, Berlin, 421 p. http://dx.doi.org/10.1007/1-4020-3702-3

[19] Saeidi, Z. (2006) Nature of Resistance to Two-Spotted Spider Mite Tetranychus urticae Koch. (Acari: Tetranychidae) in Lycopersicon Species. PhD Dissertation, University of Agricultural Sciences Bangalore, Bangalore.

[20] Carey, J.R. (1993) Applied Demography for Biologists with Special Emphasis on Insects. Oxford University Press Inc., New York.

[21] Microsoft Execel Institute (2003) A Guide to Statistical and Data Analysis.

[22] SPSS (2004) SPSS Base 13.0 Users Guide. SPSS Inc., Chicago.

[23] Van Lenteren, J.C. and Noldus, L.P.J.J. (1990) Whitefly-Plant Relationships: Behavioral and Ecological Aspects. In: Gerling, D., Ed., Whitefly. Their Bionomics, Pest Status and Management, Intercept, Andover, 47-89.

[24] Mehrdad, A., Fathipour, Y., Kamali, K. and Moharami, S. (2004) Biology of Tetranychus 
urticae on Different Cultivars of Bean. The 16th Iranian Plant Protection Congress, Tabriz, 28 August-1 September 2004, 266.

[25] Razmjou, J., Mohammadi, M. and Hassanpour, M. (2011) Effect of Vermicompost and Cucumber Cultivar on Population Growth Attributes of the Melon Aphid (Hemiptera: Aphididae). Journal of Economic Entomology, 104, 1379-1383.

[26] Huang, Y.B. and Chi, H. (2012) Life Tables of Bactrocera cucurbita (Diptera: Tephritidae) with an Invalidation of the Jackknife Technique. Journal of Applied Entomology, 137, 327 339. http://dx.doi.org/10.1111/jen.12002

[27] Mottaghinia, L., Razmjou, J., Nouri-Ganbalani, G. and Rafiee-Dastjerdi, H. (2011) Antibiosis and Antixenosis of Six Commonly Produced Potato Cultivars to the Green Peach Aphid, Myzus persicae Sulzer. (Hemiptera, Aphididae). Neotropical Entomology, 40, 380-386.

[28] Wermelinger, B., Oertli, J.J. and Baumgärtner, J. (1991) Environmental Factors Affecting the Life-Tables of Tetranychus urticae (Acari: Tetranychidae) III. Host-Plant Nutrition. Experimental and Applied Acarology, 12, 259. http://dx.doi.org/10.1007/BF01193472

[29] Modarres Najafabadi, S.S., Vafaei Shoushtari, R., Zamani, A.A., Masoud, A. and Farazmand, H. (2011) Effect of Nitrogen Fertilization on Tetranychus urticae Koch. (Acari: Tetranychidae) Populations on Common Bean Cultivar. Middle-East Journal of Scientific Research, 8, 990-998.

Submit or recommend next manuscript to SCIRP and we will provide best service for you:

Accepting pre-submission inquiries through Email, Facebook, LinkedIn, Twitter, etc.

A wide selection of journals (inclusive of 9 subjects, more than 200 journals)

Providing 24-hour high-quality service

User-friendly online submission system

Fair and swift peer-review system

Efficient typesetting and proofreading procedure

Display of the result of downloads and visits, as well as the number of cited articles

Maximum dissemination of your research work

Submit your manuscript at: http://papersubmission.scirp.org/

Or contact ae@scirp.org 